\title{
Bias Gender dalam Berita Kasus Vanessa Angel (Analisis Wacana Kritis Sara Mills dalam detik.com)
}

\author{
Yudha Wirawanda ${ }^{*}$, Rino Andreas ${ }^{2}$, dan Vania Alayda Rahma S $^{3}$ \\ ${ }^{1,3}$ Universitas Muhammadiyah Surakarta, ${ }^{2}$ Independen \\ Email: yudha.wirawanda@ums.ac.id* \\ *corresponding author
}

Keywords:

News Discourse, Sara Mills, Gender, Woman.

\section{Kata Kunci:}

Berita Wacana, Sara Mills, Gender, Perempuan.

\begin{abstract}
News about the prostitution case that involving Vanessa Angel is interesting. In the detik.com online news portal, it gained high public attention. Comment columns on both the news portal are filled with various kinds of public opinion. The researchers selected five news from this news portal on the day of the incident and one day after the event. The data is analyzed by using the critical discourse analysis method. Researchers used Sara Mills approach in Feminist Stylistic book to analyze. Researchers argue that Vanessa was shown as a negative character in some narration. This is because she has position as a public figure and a woman. She is also positioned as an object in several sentence forms in the five stories. Researchers argue that public still put women as an object. Women as public figure are prone to be positioned inequally in media. The news writer had tried to select diction and compose sentences in a balance. But the patriarchy discourse is still found in several narratives and reading discourses. Researcher still found this ideological practice in public discourse.
\end{abstract}

\begin{abstract}
ABSTRAK
Pemberitaan kasus prostitusi yang melibatkan Vanessa Angel dalam portal berita detik.com memperoleh atensi publik yang tinggi. Kolom komentar baik di portal berita maupun akun sosial media resmi diisi berbagai macam opini publik. Peneliti memilih lima berita dari portal berita ini pada hari kejadian dan satu hari setelah kejadian. Data kemudian dianalisis dengan menggunakan metode analisis wacana kritis dengan pendekatan Sara Mills dalam buku Feminist Stylistic. Dari pembahasan, peneliti melihat bahwa Vanessa sebagai perempuan dan selebritis ditampilan sebagai karakter yang negatif dalam kasus ini. Selain itu, Vanessa juga diposisikan sebagai objek dalam beberapa bentuk kalimat dalam kelima berita tersebut. Peneliti melihat bahwa wacana patriarki di Indonesia masih memosisikan perempuan dan public figure sebagai sosok yang memiliki nilai berita tinggi, namun juga rentan untuk diposisikan secara tidak berimbang. Peneliti juga melihat bahwa penulis berita sudah berusaha untuk memilih diksi dan menyusun kalimat secara seimbang. Namun wacana ideologi patriarki masih terlihat dalam beberapa narasi dan pembacaan produksi dan konsumsi wacana publik di portal berita secara khusus dan wacana di khalayak secara umum.
\end{abstract}




\section{PENDAHULUAN}

Pada tanggal 5 Januari 2019, beredar kabar tertangkapnya artis atas dugaan kasus prositusi online. Tidak lama berselang berbagai media online di Indonesia kemudian beramai-ramai memberitakan kasus yang melibarkan artis FTV Vanessa Angel di Surabaya. Pemberitaan berbagai media mainstream tersebut mendapatkan perhatian khalayak karena memiliki nilai berita. Beberapa hal yang menjadi perhatian publik adalah pertama, terlibatnya artis terkenal beserta tarifnya. Kedua, perisiwa baru terjadi di awal tahun 2019 dan viral di media sosial. Ketiga, peristiwa ini berimplikasi pada pengusutan kasus yang lebih dalam atas pelaku utama di kalangan artis.

Berita tersebut mengandung nilai berita yang tinggi dan menjadi konsumsi khalayak banyak. Jika dilihat dari perspektif wacana, sebagai sebuah produk wacana, tentu berita yang disajikan tidak netral dan objektif. Berita yang tersusun dari bahasa dalam pandangan wacana selalu memiliki muatan ideologis, baik sengaja maupun tidak. Asumsi dasar dari wacana adalah bahasa digunakan manusia untuk berbagai macam fungsi dan memiliki berbagai macam konsekuensi. Bahasa dapat digunakan untuk memerintah, memengaruhi, mendeskripsi, mengiba, memanipulasi, menggerakkan kelompok, atau membujuk (Udasmoro, 2016). Dengan kata lain, kita dapat melihat relasi kuasa wacana suatu masyarkat dari bahasa. Lewat bahasa dalam berita dalam kasus Vanessa Angel ini, kita bisa melihat bagaimana wacana terkait gender di Indonesia. Bahasa bukanlah sesuatu yang netral melainkan memiliki muatan ideologi tertentu yang dibentuk dan membentuk produsen dan konsumen teks (Fauzan, 2014). Karena itu bahasa tidak lepas dari bagaimana konstruksi dan kontestasi ideologi dari produsen dan konsumen teks

Wacana adalah sebuah bentuk aksi sosial yang memainkan peran dalam meproduksi dunia sosial (Udasmoro, 2018). Wacana tidak bisa lepas dari bahasa. Bahasa merupakan mekanisme kontrol sosial yang kuat. Bahasa menentukan pra-syarat untuk mengembangkan praktik sosial dan persetujuan sosial (Haryatmoko, 2016). Dalam bahasa lain, Wening Udasmoro (2018) menyebut bahwa bahasa ikut mentrukturkan dan distrukturkan. Lewat bahasa, praktik sosial diteguhkan, dilegitimasi, atau dideligitimasi. Praktik sosial ini termasuk bagaimana gender diwacanakan di media.

Wacana gender di Indonesia tidak lepas dari budaya patriarki. Sistem budaya patriarki yang beredar di masyarakat melandasi aspek identitas, subjektivitas dan seksualitas ini menghasilkan stereotip bahwa perempuan adalah makluk yang lemah lembut, cantik, emosional, pasif dan keibuan, sedangkan laki-laki adalah makhluk yang kuat, agresif, dan perkasa. Adanya pencitraan tersebut dapat menimbulkan kesan diskriminasi terhadap kaum perempuan (Irwanto, Kusumawati, dan Hariatiningsih, 2018).

Budaya partiarki merupakan perwujudan dari perbedaan gender yang melahirkan ketidakadilan gender baik melalui mitos-mitos, sosialisasi, kultur, dan kebijakan pemerintah telah melahirkan hukum yang tidak adil bagi perempuan (Arivia, 2004, dalam Irwanto, Kusumawati, dan Hariatiningsih, 2018). Di Indonesia wacana patriarki direproduksi lewat berbagai norma, hukum, termasuk narasi di media. Penelitian Rengkaningtias (2018) misalnya menyebutkan bahwa narasi perempuan di media massa seringkali diposisikan sebagai objek ataupun sebagai subjek, maka mereka menjadi subjek yang menjadi penyebab suatu masalah.

Praktik tersebut seringkali berjalan seolah natural. Hal inilah yang berusaha dibongkar oleh analisis wacana kritis. Ideologi patriarki yang membentuk wacana bias gender direproduksi lewat narasi tertentu sehingga dianggap normal dan wajar. Wacana melihat pengidentifikasian simbol-simbol secara terus menerus menjadikan wacana sebuah common sense, yang dianggap umum dan wajar (Udasmoro, 2018). Padahal dalam wacana selalu ada kontestasi ideologi yang berusaha merebut legitimasi dan mendeligitimasi wacana yang lain. Analisis wacana berkonsentrasi pada relasi kuasa yang terlibat dalam kontestasi tersebut. Namun wacana tidak berusaha untuk mencari siapa yang benar atau salah. Lewat analisis wacana, peneliti harus menemukan berbagai penyelesaian yang emansipatif dari setiap permasalahan yang diteliti.

Sebagai sebuah produk budaya, maka berita dalam media massa tidak lepas dari kontestasi ini. Portal berita detik. com dipilih selain karena popularitasinya, juga karena media menyediakan kolom komentar sehingga pembaca dapat berkomentar dan melihat komentar pengguna lain. Hal ini membantu peneliti untuk melihat aspek produksi dan konsumsi teks dari suatu wacana. Wacana patriarki yang bias gender masih kuat di Indonesia, sehingga narasi mengenai perempuan di media tidak bisa lepas dari kontestasi ideologi tersebut di ruang publik. Pembuat berita dan media tidak bisa menjadi aktor dominan yang menentukan wacana. Ada posisi pembaca yang menentukan wacana terkait perempuan di media. Kasus Vanessa Angel ini menarik karena selain melibatkan public figure, kasus ini juga mendapat atensi yang tinggi dari publik. Kita bisa melihat berbagai opini yang diutarakan publik di kolom komentar. Hal ini tentu dapat memberi gambaran bagaimana ideologi publik terkait perempuan di media yang terlibat kasus. Karena itu peneliti ingin melihat bagaimana wacana terkait perempuan dalam kasus Vanessa Angel dilihat dari teks berita dan wacana publik terkait kasus tersebut. Penelitian ini tidak berusaha menghakimi media dan menempatkan dalam posisi salah dan benar karena hal ini bukanlah tujuan dari analisis wacana kritis. Penelitian ini bertujuan untuk membongkar berbagai praktik wacana, baik dalam teks maupun produksi makna di publik, yang masih bias gender. Dengan adanya penelitian ini, maka diharapkan berbagai pihak yang membentuk dan terbentuk wacana gender; media, akademisi, dan publik, mampu memproduksi wacana yang lebih berimbang terkait dengan gender. 


\section{METODE PENELITIAN}

Penelitian ini merupakan penelitian kualitatif yang menggunakan pendekatan analisis wacana kritis model Sara Mills. Analisis wacana kritis memahami wacana tidak semata-mata sebagai suatu metode studi bahasa, tetapi juga merupakan langkah untuk menghubungkan bahasa dengan wacana dan konteks. Konteks yang dimaksud adalah konteks praktik kekuasaan yang bertujuan untuk memarginalkan individu atau kelompok tertentu (Fauzan, 2014). Eriyanto (dalam Afrialldi dan Putra, 2018) mengatakan bahwa model Sara Mills berpusat pada bagaimana posisi dari aktor-aktor sosial, penempatan gagasan, ataupun peristiwa diletakan dalam teks. Sara Mills sendiri dalam bukunya Feminist Stylistic (1995) berusaha melihat wacana dari tiga level. Level pertama adalah analisis level kata. Di level ini peneliti harus melihat pilihan diksi oleh penulis. Bahasa tidaklah netral. Hal ini bahkan bisa dilihat dari pilihan kata yang dapat memunculkan penafsiran tertentu. Peneliti mengumpulkan dan memilah berbagai pemilihan kata yang ada di berita dan menganalisis secara kritis diksi tersebut dalam konteks wacana patriarki di Indonesia. Selanjutnya peneliti menganalisis level kalimat. Peneliti mengumpulkan dan memilih berbagai kalimat yang memunculkan karakter laki-laki dan perempuan serta kalimat yang berkaitan dengan relasi laki-laki dan perempuan dalam lima berita tersebut. Di level ini peneliti melihat bagaimana gender diposisikan sebagai subjek atau objek dan bagaimana pemilihan idiom atau metafor dalam berita. Level terakhir adalah analisis level wacana. Di sini peneliti melihat bagaimana ideologi bekerja lewat produksi dan konsumsi teks di publik terkait narasi perempuan yang terlibat kasus di media. Peneliti menganalisis berbagai komentar pengguna detik serta menggunakan rujkan pustaka lain untuk mengkritisi wacana perempuan dalam media massa di Indonesia.

Subjek penelitian ini adalah lima berita kasus Vanessa Angel di portal berita detik.com, baik yang muncul di news. detik.com ataupun hot.detik.com. Teknik sampling yang digunakan adalah purposive sampling untuk mendapatkan data yang sesuai dengan kriteria (Palys dalam Given, 2008). Peneliti memilih berita pada hari kejadian kasus dan keesokannya. Respon publik yang tinggi membuat media memberikan perhatian pada kasus ini, sehingga ada kemungkinan mereka lebih awas dengan narasi bias gender dalam penyusunan berita lanjutan. Jadi penelitian ini melihat bagaiman respon langsung dari media pada hari kejadian terkait dengan kasus ini. Teknik pengumpualan data melalui dokumetasi dan studi pustaka yang dibagi menjadi dua jenis data yaitu data primer yang terdiri dari berita detik.com dan komentar pembaca di portal tersebut serta data sekunder terdiri dari jurnal dan buku.

\section{HASIL DAN ANALISIS}

\section{A. Menikmati Lewat Bahasa}

Bahasa menjadi alat yang sering digunakan untuk mengkonstruksi kenyataan sosial. Kalimat dan paragraph masih menjadi alat yang digunakan untuk menjelaskan persoalan sosial (Udasmoro, 2018). Sara Mills juga menggunakan bahasa untuk melihat relasi kuasa terkait dengan gender. Bahasa merupakan produk dari negosiasi terkait dengan makna di masa lalu maupun sekarang (Mills, 2008). Bahasa publik terkait dengan perempuan yang terlibat kasus di berita juga menunjukkan negosiasi dan kontestasi ideologi.

Mills melihat bahwa pemilihan kata terkait dengan perempuan di media seringkali membuat perempuan dalam posisi pasif atau negatif(Mills, 1995). Misalnya dalam pemilihan judul berita "Polisi: Pemesan Vanessa Angel Pengusaha" (https://news.detik.com/berita/d-4372460/polisi-pemesan-vanessa-angel-pengusaha?_ga=2.146006196.1645 934867.1548146723-1075236631.1526727924). Pemilihan kata "pemesan" memunculkan relasi kuasa yang tidak seimbang antara yang dipesan dan yang memesan. Kata "memesan" sering digunakan dalam percakapan untuk membeli barang dan jasa, bukan manusia. Dalam konteks ini, sosok Vanessa direduksi menjadi komoditas yang bisa dipesan. Mills (1995) melihat bahwa konsekuensi pembatasan aspek perempuan sebagai objek memiliki konsekuensi penggambaran perempuan hanya sebagai barang. Kita sering menggunakan kata "memesan" untuk menggunakan jasa, namun bukan diperuntukkan bagi penyedia jasa. Kita memesan ojek, bukan memesan pengemudi ojek. Kita memesan makanan, bukan memesan koki. Di sini peneliti melihat bahwa pemilihan kata ini bias karena konstruksi makna yang muncul karena penggunaannya. Cameron (1990, dalam Mills: 1995) menyebutkan bahwa beberapa pilihan kata memunculkan konotasi yang negatif bagi perempuan.

Pemosisian Vanessa sebagai objek juga dilihat dari publikasi tarif jasa. Dengan menyebutkan pada judul bahwa “Tarif Prostitusi online Artis VA capai Rp 80 Juta” (https://news.detik.com/berita-jawa-timur/d-4372221/tarif-prostitusionline-artis-va-capai-rp-80-juta? ga=2.146006196.1645934867.1548146723-1075236631.1526727924), maka pembaca memfokuskan pada nominal tersebut. Dengan menggunakan kata “capai”, maka penulis memosisikan tarif 80 juta tersebut dalam posisi nominal yang tinggi. Dengan mengaitkan tariff tersebut dengan kata artis dan prostitusi online, maka pembaca dapat memaknai sosok VA sebagai pelaku prostitusi yang bertarif sangat mahal. Sehingga dalam logika pemesanan barang dan jasa, VA selain diposisikan negatif karena kasus prostitusi juga diposisikan negatif karena mahalnya tariff tersebut.

Dalam beberapa judul berita dan kalimat, Vanessa diposisikan sebagai pihak yang pasif dalam proses pengungkapan kasus. Disebutkan dalam kalimat "Vanessa ditangkap Bersama model majalah dewasa Avriella Shaqqila di sebuah hotel di Surabaya” (https://news.detik.com/berita/d-4372490/polisi-segera-tentukan-status-vanessa-angel-di-kasus-prostitusionline? ga=2.186179753.1645934867.1548146723-1075236631.1526727924). Dalam kalimat ini pembaca fokus pada nama-nama objek, yaitu dua pelaku yang berjenis kelamin perempuan. Tidak disebutkan dalam kalimat tersebut siapa 
yang menangkap atau dengan siapa mereka ditangkap. Dalam berbagai narasi pemberitaan media di Indonesia, seringkali karakter perempuan ditonjolkan ketika dia berbuat negatif, namun tidak diimbangi dengan penonjolan karakter laki-laki. Bahkan dalam kalimat tersebut, posisi subjek yang dalam konteks ini berbuat benar juga tidak disebutkan. Penghilangan karakter-karakter tersebut membuat pembaca fokus pada dua karakter yang disebut namanya yang keduanya perempuan dan keduanya juga pelaku kasus tersebut.

Penelitian Rengkaningtias (2018) menjelaskan bagaimana perempuan dalam wacana patriarki diposisikan sebagai objek yang pasif atau pihak yang aktif sebagai sumber suatu masalah. Karakter perempuan dalam kasus Vanessa Angel sering diposisikan aktif sebagai pelaku kasus dan menjadi pihak pasif yang ditangkap pihak berwenang. Hal ini tidak menjadi bias jika berita menyebutkan pelaku laki-laki secara mendetail dalam kasus ini. Penyebutan pelaku dalam berita bersifat menyembunyikan, dengan hanya menyebutnya sebagai "pengusaha". Jika memang acuannya nilai berita, maka Vanessa menjadi pihak yang dipojokkan akibat dua atribut yang dia sandang: sebagai perempuan dan sebagai public figure. Namun, kedua hal tersebut tidak lantas membuat wajar dan normal perilaku mereka diumbar ke publik dan diadili oleh publik.

Pemilihan kata yang sama jika disematkan pada laki-laki menimbulkan makna yang berbeda jika disematkan pada perempuan. Salah satu judul berita terkait dengan kasus ini adalah "Vanessa Angel Si Cantikyang Hobi Gonta-ganti Pacar Kini Terjaring Prostitusi Online”(https:/hot.detik.com/celeb/d-4372270/vanessa-angel-si-cantik-yang-hobi-gonta-gantipacar-kini-terjaring-prostitusi-online?_ga=2.127848526.2118677393.1548079545-1514287825.1547471417). Pilihan frasa "hobi gonta-ganti pacar" dalam wacana di Indonesia memberikan makna yang negatif bagi perempuan. Perempuan yang diwacanakan dengan nilai kesetiaan hilang jika gonta-ganti pacar. Berbeda dengan laki-laki yang menjadi "pejantan" jika sanggup gonta-ganti pacar. Mills (1995) juga menyebutkan bahwa penyebutan karakter perempuan di media seringkali dihubungkan dengan aspek ketubuhan. Hal ini bisa kita lihat bahwa sosok Vanessa Angel harus dihubungkan dengan istilah "si cantik", yang tentu berhubungan dengan aspek ketubuhannya. Publik ikut menikmati penggambaran karakter ini lewat pemaknaan yang muncul dari berbagai pemilihan kata tersebut. Dalam judul ini Vanessa juga disudutkan lewat kasus ini dengan pemilihan kata "terjaring". "Terjaring" bukanlah pilihan kata yang positif untuk penangkapan. Jelas tidak ada yang membanggakan dari proses ditangkap polisi dalam kasus kriminal. Namun pilihan kata sinonim lain seperti "terlibat" memunculkan konotasi yang berbeda dibandingkan "terjaring". Pilihan ini jelas mengajak pembaca mengkonotasikan praktik lain yang menggunakan kata kerja "jaring”, misalkan menjaring ikan, yang memosisikan ikan sebagai objek buruan yang dinikmati oleh si penjaring. Lakoff and Johnson (1980, dalam Mills, 1995) menyebutkan metafor dapat membatasi pemaknaan dalam penggunaan bahasa. Makna terjaring menjadi metafor posisi Vanessa dalam kasus ini ibarat ikan yang ditangkap nelayan dan dapat diapakan saja sesuai kewenangan penagkap.

Pilihan kata dalam berita juga dapat menyudutkan karena berpotensi memunculkan pengadilan lewat media, atau trial by press. Vanessa, terlepas melakukan sangkaan atau tidak, belumlah terbukti secara sah di pengadilan melakukan kriminal. Namun pemilihan diksi memosisikan Vanessa seolah telah melakukan hal tersebut. Misalnya dalam judul disebutkan Vanessa terjaring prostitusi online. Ikan yang sudah terjaring sudah pasti tertangkap dan dalam kewenangan penuh dari penangkapnya. Namun dalam kasus ini, seperti diungkapkan di kalimat berita, "Fakta-Fakta Vanessa Angel ditangkap Polda Jawa Timur karena dugaan prostitusi online” (https://news.detik.com/berita/d-4372435/ fakta-fakta-vanessa-angel-ditangkap-polisi-terkait-prostitusi-online?_ga=2.146006196.1645934867.15481467231075236631.1526727924), pembaca judul bisa menyangka bahwa Vanessa telah melakukan tindakan prostitusi online. Dengan tidak menambah keterangan status sangkaan, kalimat dalam judul ini dapat memunculkan makna yang berbeda terkait posisi Vanessa dalam kasus ini.

Menurut Mills (1995), perempuan di media juga seringkali tidak ditampilkan secara mandiri, namun disandingkan dengan hal lain, misalnya sosok laki-laki di sekitarnya. Penyandingan ini berbeda dengan laki-laki, yang seringkali disandingkan dengan prestasi atau karirnya. Misalnya dalam kalimat "Eks tunangan Didi Soekarno itu digrebek setelah ada laporan masyarakat terkait transaksi prostitusi online”. Perlu ada keterangan bahwa Vanessa merupakan mantan tunangan dari Didi. Padahal keterangan ini tidak relevan dengan kasus dan tidak menambah informasi apapun terkait kasus.

Pemilihan kata dan penyusunan kalimat tidak menunjukkan kesengajaan dari penulis atau media untuk melanggengkan bias gender di media. Media sudah memilih diksi yang tidak vulgar dan narasi yang melecehkan perempuan. Namun dari beberapa pemilihan kata dan penyusunan kalimat ini, peneliti melihat bahwa perempuan masih menjadi sosok yang sering diposisikan sekaligus sebagai objek, dikonotasikan secara negatif, dan pelaku utama dari kasus atau masalah.

\section{B. Wacana yang Mengadili Perempuan}

Perempuan dalam berbagai pemberitaan di media, terutama yang berkaitan dengan kriminal seringkali diposisikan sebagai objek (Nugroho, 2012 dan Indrasty, Wibawa, dan Rojudin, 2018). Dalam berbagai kasus, posisi subjek diperankan oleh pembaca, penulis, atau polisi. Misalnya, dalam kasus Vanessa Angel, wacana yang muncul di publik dapat dilihat dari berbagai tanggapan di kolom komentar portal berita, kicauan di sosial media, atau percakapan sehari-hari. Publik membahas bagaimana Vanessa melakukan tindakan tercela dengan terlibat pada kasus tersebut. Padahal dalam perkembangannya, 
Vanessa belum dalam posisi terdakwa dan bahkan pada tanggal 6 Januari 2019 dia belum menjadi tersangka. Namun publik sudah kadung mengadili Vanessa sebagai pihak yang bersalah. Bahkan publik sudah banyak mencari informasi privat terkait dengan karakter Vanessa. Mills (1995) menyebutkan bahwa wacana terkait dengan perempuan berkaitan dengan konstruksi karakter perempuan tertentu yang sesuai dengan wacana dominan. Wacana yang memosisikan perempuan sebagai objek atau sumber masalah, misalnya, direproduksi oleh ideologi dominan di masyarakat tersebut. Perempuan yang dalam praktik sosial diposisikan marjinal akan diadili pribadinya jika melakukan kesalahan. Hal yang sama terjadi bagi sosok laki-laki yang juga public figure. Baik laki-laki maupun perempuan public figure jelas memiliki hak untuk informasi privat. Namun jika informasi privat ini dikonsumsi publik seolah wajar dan alami, padahal tidak demikian. Namun berbeda dibandingkan laki-laki, perempuan public figure harus menerima konsekuensi termarjinalkan dua kali, baik sebaik sosok terkenal maupun sebagai perempuan. Sebagai sosok terkenal, Vanessa diadili lewat gaya hidupnya. Banyak tanggapan di kolom komentar yang mengaitkan tarif tinggi dengan gaya hidup mewah. Di sisi lain, sebagai perempuan, Vanessa juga harus menerima konsekuensi untuk diumbar masalah ketubuhannya. Mills (2008) menyebutkan bahwa perempuan secara tidak langsung diasosiasikan secara negatif lewat stereotip dan asosiasi. Asosiasi bahwa gaya hidup mewah dengan praktik prostitusi memarjinalkan Vanessa sebagai public figure. Di sisi lain asosiasi tubuh Vanessa sebagai barang dagangan juga memarjinalkan dirinya sebagai perempuan. Dalam wacana patriarki, publik seolah memiliki "hak" untuk mengadili penjahat, apalagi perempuan, apalagi orang terkenal. Seolah "hak" ini terbentuk dengan wajar dan alamiah, padahal memosisikan pihak yang teradili sebagai objek yang tersudutkan dan tidak memiliki kesempatan membela diri. Hal ini karena ketika kasus memuncak, perempuan yang diposisikan melakukan kesalahan tidak dianggap sebagai sosok yang terpercaya atau bahkan tidak diberi kesempatan bersuara secara adil. Menurut Mills (1995) perempuan dalam narasi di media seringkali tidak diberi kesempatan menuturkan pengalamannya secara rinci, sehingga sudut pandangnya dihilangkan dan diganti dengan narasi publik.

Narasi publik dalam kasus Vanessa tidak lepas dari wacana dari ideologi patriarki yang bias gender. Misalnya dari deskripsi pelaku kasus tersebut. Vanessa sebagai pelaku perempuan dideskripsikan secara detail, baik aktivitas sebelum ataupun ketika ditangkap. Hal ini berbeda dengan pelaku laki-laki yang disamarkan lewat sosok status karir, atau hanya disebut nama depan. Hal ini memang tidak lepas dari posisi Vanessa sebagai selebritis. Namun penggambaran detail yang berhubungan dengan aspek ketubuhan maupun foto yang dipilih dalam berita merupakan konsekuensi sebagai perempuan. Kedua aspek tersebut, keterkenalan dan gender, memunculkan bias yang menjadikan sosok Vanessa diadili dalam kontestasi wacana.

Mills (1995) menggunakan istilah schemata untuk menyebut kerangka pemahaman yang memosisikan anggapan dalam sebuah wacana sebagai sesuatu yang solid dan alami. Seksisme dalam masyarakat beroperasi dalam level schemata. Misalnya jika publik merasa "berhak" untuk mengadili dan membongkar privasi pelaku kasus, hanya karena dia terkenal dan hanya karena dia perempuan. Hal tersebut merupakan praanggapan yang dianggap wajar, padahal memojokkan dan memarjinalkan objek. Perlu diingat bahwa pada saat kasus kejadian, Vanessa bahkan belum diposisikan polisi sebagai tersangka. Menurut Haryatmoko (2016), konstruksi muncul ketika orang memberi makna kepada fenomena atau terlibat dalam aktivitas sosial. Bagi analisis wacana kritis, proses mental ini konstruktif. Dalam wacana selalu sudah ada unsur kepecayaan yang sudah dimiliki sebelum memulai komunikasi yang tergantung pada budaya aktor sosial. Jadi jika publik dan memosisikan Vanessa sebagai pihak termarjinalkan, bersalah, dan perlu dinasehati maka ada ideologi yang bekerja di praktik sosial ini. Ideologi ini bekerja sehingga wacana terkait perempuan menjadi biasa dan akhirnya memosisikan perempuan dan laki-laki dalam relasi subjek dan objek yang tidak setara, padahal keduanya aktor dari perilaku yang sama.

Pemosisian pembaca, menurut Mills (1995), memungkinkan kita untuk setuju dengan schemata tertentu atau berusaha untuk bereaksi dan mengubahnya. Dalam berbagai tanggapan di kolom komentar, sudah ada beberapa pengguna yang mengritik komentar pengguna lain yang melecehkan atau mengadili Vanessa. Hal ini berhubungan dengan kerangka pengalaman dan pengetahuan pembaca tersebut. Setiap pembaca memiliki kerangka pengalaman yang berbeda, namun kerangka itu jelas tidak bisa lepas dari wacana dominan. Menurut Mills (1995) wacana dominan seringkali memosisikan perempuan sebagai pihak yang perlu diceramahi dan dinasehati. Dalam kasus ini, pembaca yang menerima praanggapan tersebut akhirnya turut menasehati dan menyeramahi Vanessa. Hal ini karena pemosisian pembaca pada subjek narasi dan Vanessa sebagai objek yang harus dibenahi karena telah melakukan tindakan kriminal.

Wacana dominan di Indonesia memang tidak lepas dari ideologi patriarki. Sebagai sebuah ideologi, maka patriarki direproduksi dan dilanggengkan lewat berbagai praktik sosial, termasuk berkomentar mengenai kasus Vanessa. Hal ini dilakukan secara terus menerus sehingga kita merasa bahwa hal ini menjadi suatu yang wajar. Praktik sosial dari wacana juga termasuk pembiasaan dari penggunaan bahasa. Sebagai sebuah system kepercayaan, jelas ideologi dipercaya oleh banyak orang. Hal ini membuat ideologi patriarki yang muncul dalam wacana gender terkait kasus Vanessa juga direproduksi oleh aktor-aktor di dalamnya, termasuk pembaca. Produksi makna oleh pembaca dan praktik sosial yang dilakukan pembaca juga melanggengkan pemaknaan dari setiap bahasa yang digunakan dalam media. Karena itu dengan membongkar kuasa wacana lewat bahasa dan narasi di berbagai berita ini kita bisa melihat bahwa hal tersebut tidaklah netral dan wajar. Ada wacana patriarki yang masih bias gender. Hal ini perlu diperhatikan media dan publik jika ingin menampilkan wacana yang lebih egaliter secara gender. 


\section{KESIMPULAN}

Media detik.com dalam pemberitaan mengenai kasus Vanessa Angel dalam beberapa aspek masih masuk dalam arus wacana patriarki. Di beberapa berita karakter perempuan masih dalam posisi yang menyudutkan dan tidak menguntungkan. Hal ini tidak salah karena pemosisian pembaca memperkuat wacana yang muncul dari setiap pemaknaan kata dan kalimat. Kekuatan wacana yang dibangun menempatkan posisi perempuan sebagai objek tatapan laki-laki dalam wacana publik. Objektifikasi yang dilakukan media dalam teks berita, mendorong subjek semakin termajinalkan. Ketika karakter perempuan sebagai subjek, maka seringkali diposisikan sebagai sumber masalah. Perempuan sekaligus public figure mengalami bias gender dalam narasi di media.

Dalam kasus kriminal Vanessa Angel, penggunaan kata, kalimat, maupun foto dalam lead dan badan berita yang menampilkan perempuan sebagai seksual yang menjadi tatapan publik. Nilai berita kasus ini sangat tinggi terlihat dengan respon khalayak yang banyak memberikan respon like, share, dan komentar. Penulis juga terlihat berhati-hati dalam memilih diksi agar lebih proporsional dalam mengkonstruksikan perempuan. Namun wacana patriarki yang masih kuat di media membuat karakter utama dalam narasi ini dipojokkan, baik sebagai perempuan, pelaku kriminal, sekaligus public figure. Peneliti melihat bahwa media seperti detik.com menunjukkan upaya agar tidak terjebak pada pelecehan karakter berbasis gender. Namun pemilihan diksi tertentu ternyata dalam produksi makna di publik masih terjebak pada wacana patriarki yang bias gender. Dengan membongkar praktik yang seolah wajar tersebut, maka diharapkan praktik demikian dapat diminimalisir.

\section{DAFTAR PUSTAKA}

Afrialldi, R., \& Putra, D. K. S. (2018). Analisis Wacana Hegemoni Melalui Film Dokumenter'jakarta Unfair'. eProceedings of Management, Vol.5, No.2.

Udasmoro, W (Ed.). 2018. Hamparan Wacana dari Praktik Ideologi, Media hingga Kritik Poskolonial. Yogyakarta: Penerbit Ombak.

Fauzan, U. (2014). Analisis Wacana Kritits dari Model Fairclough hingga Mills. Jurnal Pendidik, Vol.6, No.1.

Given, L.M. (2008). The Sage Encyclopedia of Qualitative Research Methods Vol 2. Los Angeles: Sage Pub.

Haryatmoko (2016). Membongkar Rezim Kepastian: Pemikiaran Kritis Post-Strukturalis. Yogyakarta: Kanisius.

Indrasty, R., Wibawa, D., \& Rojudin. (2018). Gender dalam Kasus Kekerasan terhadap Perempuan di Media Online. Jurnal Ilmu Jurnalistik Vol.3, No.1.

Irwanto, Kusumawati, N., \& Laurensia Retno Hariatiningsih. (2018). Narasi Feminisme Dalam Sinetron Dunia Terbalik. Jurnal Ilmu Komunikasi (J-IKA), Vol.VNo.2.

Mills, S. (1995). Feminist stylistics. London: Routledge.

Mills, S. (2008). Language and Sexism. Cambridge: Cambridge University Press

Nugroho, Y.K. (2012). Analisis Wacana Berita Pemerkosaan Pada Surat Kabar Indopos. Wacana Vol.XI, No.4.

Rengkaningtias, A.U. (2018). Perempuan Dalam Pandangan Media: Labelisasi Perempuan Sebagai Agent of Problem pada Koran Merapi. Jurnal Communication Vol.9, No.1.

\section{LINK BERITA}

https:/hot.detik.com/celeb/d-4372270/vanessa-angel-si-cantik-yang-hobi-gonta-ganti-pacar-kini-terjaring-prostitusionline? ga=2.127848526.2118677393.1548079545-1514287825.1547471417

https://news.detik.com/berita/d-4372490/polisi-segera-tentukan-status-vanessa-angel-di-kasus-prostitusi-online? ga $=2.186179753 .1645934867 .1548146723-1075236631.1526727924$

https://news.detik.com/berita/d-4372460/polisi-pemesan-vanessa-angel-pengusaha?_ $\mathrm{ga}=2.146006196 .1645934867 .1548146723-1075236631.1526727924$

https://news.detik.com/berita/d-4372435/fakta-fakta-vanessa-angel-ditangkap-polisi-terkait-prostitusi-online? $\mathrm{ga}=2.146006196 .1645934867 .1548146723-1075236631.1526727924$

https://news.detik.com/berita-jawa-timur/d-4372221/tarif-prostitusi-online-artis-va-capai-rp-80-juta? $\mathrm{ga}=2.146006196 .1645934867 .1548146723-1075236631.1526727924$ 